\title{
REVIEW
}

\section{Inherited destiny? Genetics and gestational diabetes mellitus}

\author{
Richard M Watanabe*
}

\begin{abstract}
Despite years of investigation, very little is known about the genetic predisposition for gestational diabetes mellitus (GDM). However, the advent of genome-wide association and identification of loci contributing to susceptibility to type 2 diabetes mellitus has opened a small window into the genetics of GDM. More importantly, the study of the genetics of GDM has not only illuminated potential new biology underlying diabetes in pregnancy, but has also provided insights into fetal outcomes. Here, I review some of the insights into GDM and fetal outcomes gained through the study of both rare and common genetic variation. I also discuss whether recent testing of type 2 diabetes mellitus susceptibility loci in GDM case-control samples changes views of whether GDM is a distinct form of diabetes. Finally, I examine how the study of susceptibility loci can be used to influence clinical care, one of the great promises of the new era of human genome analysis.
\end{abstract}

\section{Overview}

Gestational diabetes mellitus (GDM) refers to hyperglycemia that first presents during pregnancy and typically resolves itself post-partum. There are inadequate data on the prevalence of GDM; however, in 1988 it was estimated that about $4 \%$ of pregnancies in the United States were complicated by diabetes, with $88 \%$ of these accounted for by GDM [1]. More recent data suggest that, as with the overall increased prevalence of diabetes, rates of GDM are significantly increasing [2]. For example, Dabelea and colleagues [3] examined trends in singleton pregnancies from the Kaiser Permanente health maintenance organization of Colorado between 1994 and 2002 and noted that rates of GDM increased two-fold in all ethnic

*Correspondence: rwatanab@usc.edu

Department of Preventive Medicine, Keck School of Medicine of USC, 1540 Alcazar St, CHP-220, Los Angeles, CA 90089-9011, USA groups. Accurate data on the prevalence and incidence of GDM are likely to become available given that screening during pregnancy is almost routine and consistent diagnostic criteria are now being implemented [4].

Hyperglycemia during pregnancy, whether due to GDM or other forms of diabetes, has implications for mother, developing fetus, and child. Women diagnosed with GDM have a higher risk for future type 2 diabetes mellitus (T2DM) [5]. Kjos et al. [6] were the first to demonstrate that this risk was even higher in Hispanic women with previous GDM by showing that $45 \%$ of a cohort followed for 5 years post-partum developed T2DM despite plasma glucose returning to non-diabetic levels. The observation that previous GDM increases risk for future T2DM was subsequently confirmed in other ethnic groups [7]. Women with GDM have a higher rate of caesarean section, gestational hypertension, and large for gestational age deliveries [8]. Maternal diabetes has been shown to be associated with increased risk for macrosomia [8,9], and GDM-associated macrosomia is associated with increased rates of a variety of complications, including hypoglycemia and respiratory distress syndrome [10].

Pettitt et al. [11] were among the first to show the association between maternal hyperglycemia and increased risk for babies large for their gestational age or macrosomia, with implications for additional morbidities in adulthood [12]. For example, Pima Indian women whose birth weight was over 4,500 g had a four-fold higher risk of developing GDM when they became pregnant as adults [12]. Also, in siblings born from pregnancies discordant for diabetes, but who were raised in similar environments, the sibling born from the diabetic pregnancy was more obese than the sibling born from the non-diabetic pregnancy [13].

New insights into pregnancy-related outcomes are now becoming available from the Hyperglycemia and Adverse Pregnancy Outcome (HAPO) study [14]. HAPO is a prospective observational study of over 25,000 pregnant women in nine countries who underwent an oral glucose tolerance test (OGTT; 75 g glucose administered orally, followed by blood sampling at 2 hours) at 24 to 32 weeks of gestation, with assessment of several maternal and 
Table 1. Characteristics and treatment modalities of different forms of diabetes mellitus

\begin{tabular}{|c|c|c|}
\hline & Characteristics & Treatment modalities \\
\hline MODY & $\begin{array}{l}\text { A series of autosomal dominant forms of diabetes. Mutations in genes } \\
\text { predisposing to six different forms of MODY have been identified. } \\
\text { MODY2, which results from mutations in glucokinase (GCK), is unique } \\
\text { among MODYs in that it results in modest hyperglycemia that does } \\
\text { not require pharmacological intervention. MODY is characterized by } \\
\beta \text {-cell dysfunction in the absences of insulin resistance or obesity }\end{array}$ & $\begin{array}{l}\text { MODY1, MODY } 3 \text { and MODY } 4 \text { are typically treated by oral } \\
\text { hypoglycemics. MODY5 and MODY6 are typically treated using insulin } \\
\text { therapy. MODY2 can be managed by lifestyle modification alone }\end{array}$ \\
\hline GDM & $\begin{array}{l}\text { Hyperglycemia that presents during pregnancy and typically resolves } \\
\text { itself post-partum. GDM is characterized by insulin resistance and } \\
\beta \text {-cell dysfunction. Women with previous GDM are at high risk for } \\
\text { future T2DM }\end{array}$ & $\begin{array}{l}\text { Lifestyle modification is the first choice to manage GDM. However, } \\
\text { if glycemic control cannot be achieved, then pharmacological } \\
\text { intervention, primarily insulin therapy, can be implemented }\end{array}$ \\
\hline T2DM & $\begin{array}{l}\text { The predominant form of diabetes characterized by insulin resistance } \\
\text { and } \beta \text {-cell dysfunction, typically accompanied by obesity }\end{array}$ & $\begin{array}{l}\text { Lifestyle modification is recommended in all cases, but in most } \\
\text { circumstances pharmacological intervention is required. Choice of } \\
\text { therapies includes oral hypoglycemics, metformin, thiazolidinediones, } \\
\text { GLP1 mimetics, and DPP-IV inhibitors. Combination therapy has also } \\
\text { become more common in the management ofT2DM }\end{array}$ \\
\hline
\end{tabular}

fetal outcomes. The HAPO study is already providing some new insights into the management of GDM [15] and has shown that body mass index (BMI), independent of glycemia, was associated with the frequency of excess fetal growth and pre-eclampsia [16]. The HAPO study should provide many new insights into the relationship between maternal hyperglycemia and pregnancy-related outcomes.

Here, I review the current state of knowledge regarding genetic susceptibility to T2DM and its implications for GDM. The physiological implications of mutations underlying monogenic forms of diabetes and polymorphisms underlying complex forms of diabetes are also considered (Table 1). The issue of whether GDM and T2DM are distinct diseases and whether genetic information can shed additional light on this controversy are discussed. Finally, a brief discussion of the clinical implications of genetic variation is provided.

\section{The role of genetics}

\section{Evidence for a genetic basis}

The study of genetics in GDM has been relatively lacking until the recent advent of genome-wide association (GWA) studies (see below). Such studies have been partly hampered by the lack of evidence for a genetic basis for GDM. That is not to say that GDM does not have a genetic basis, but that the ability to accurately assess familiality of GDM is limited. Twin concordance rates, familial risk estimates, or heritability studies have been used to provide evidence of a genetic basis for a given phenotype. Prospective studies are complicated by the need to study related individuals presenting with GDM, a very daunting task. Retrospective studies are also fraught with difficulties. The diagnostic criteria for GDM have changed over the years [4,17-20], complicating retrospective identification of GDM cases. Screening for GDM has not been a part of routine medical care until recently.
These factors can lead to ascertainment bias and poor estimates of heritability. Finally, the very low prevalence of GDM, relative to the population and to other forms of diabetes, makes it difficult to accumulate sufficient samples for genetic studies.

Several studies have examined clustering of GDM with either type 1 or type 2 diabetes. For example, McLellan and colleagues [21] identified 14 women with a previous diagnosis of GDM with both parents available for study and noted that glucose intolerance was observed in $64 \%$ of the parents. Similarly, Martin et al. [22] showed that a higher than expected number of mothers with diabetes was observed in 91 women with GDM. These and other similar studies hint at the possibility of common genetic determinants for GDM, although the effect of in utero hyperglycemia on offspring with implications in adulthood cannot be discounted. We reported an estimated sibling risk ratio for GDM of 1.75, which was based on state-wide medical record information from the state of Washington [23]. Although this estimate suggests an increased sibling risk for GDM, it is likely this is an underestimate of the true risk given the methodological complications noted above.

\section{Glucokinase}

For a good description of candidate gene studies for GDM, see a recent review by Robitaille and Grant [24]. One issue regarding early genetic associations is that they rarely replicated across studies, partly owing to the fact that gene effects are relatively small and most candidate gene studies were under-powered. However, studies of monogenic forms of diabetes, specifically maturity-onset diabetes of the young 2 (MODY2), provided some of the first insights into the contribution of genetic variation to hyperglycemia observed during pregnancy and fetal outcomes. MODY2 is an autosomal dominant form of MODY due to mutations in glucokinase (GCK) [25-27]. 


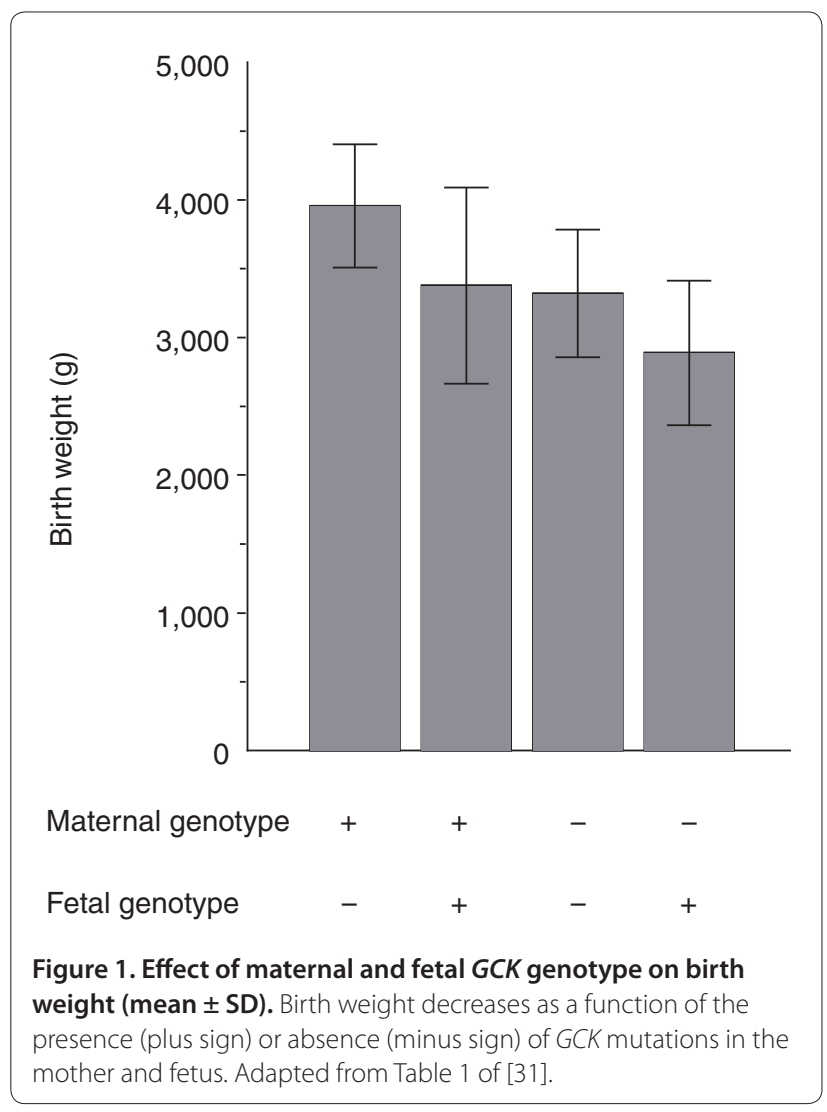

Physiological studies revealed that the hyperglycemia observed in patients with MODY2 mutations is due to a rightward shift in the insulin secretory dose response to glucose [27]. This rightward shift indicates that MODY2 patients can dynamically respond to glycemic excursions, but at a higher glucose set point. Thus, MODY2 patients are typically treated by lifestyle modification and remain modestly hyperglycemic relative to the non-diabetic population.

Early evidence suggested that females with GCK mutations frequently presented with GDM, as suggested by the observation that 7 of 11 parous women from two pedigrees with a specific $G C K$ mutation were diagnosed with GDM [28,29]. Hattersley and colleagues [30] posited that the association between low birth weight and subsequent insulin resistance in adulthood is genetically determined, presumably a result of $G C K$ mutations, and introduced the 'fetal insulin' hypothesis. An important component to this hypothesis is that low insulinmediated fetal growth in utero is determined by a defect in glucose sensing by the pancreas due to GCK mutations, resulting in reduced insulin levels during critical periods of growth and development of the fetus. In partial support of this hypothesis, they showed [30] that maternal hyperglycemia due to GCK mutations was associated with an increased birth weight that was a consequence of additive effects of the maternal and the fetal GCK genotype (Figure 1). They further showed [31] that in sibling pairs discordant for $G C K$ mutations, the sibling with the $G C K$ mutation had a lower birth weight than the sibling without the mutation. They proposed that differences in birth weight in their sample were a consequence of a direct effect of fetal GCK mutations on fetal insulin secretion and an indirect effect of maternal hyperglycemia due to GCK mutations in the mothers.

It should be noted that common variants in $G C K$ also seem to contribute to maternal hyperglycemia that subsequently affects birth weight. A large-scale metaanalysis confirmed observations from previous studies that the -30 promoter variant in GCK (rs1799884) was associated with both fasting glucose and birth weight $[32,33]$. The presence of at least one copy of the maternal A allele increased birth weight by an average of $64 \mathrm{~g}$ compared with G/G homozygous individuals, with weak evidence for an additive effect of the maternal A allele [32]. Furthermore, analysis of a subset of the data suggested that the effect of rs1799884 on fasting glucose partly explains the association with birth weight. Fetal genotype information was available on a subset of the data, but this study [32] was not able to demonstrate any interaction between maternal and fetal GCK genotypes.

\section{T2DM susceptibility loci and GDM}

The introduction of GWA has transformed the study of complex disease genetics and GWA studies of T2DM have been at the forefront of this new era of human genetics. Only three T2DM susceptibility loci had been identified before 2007: two identified by candidate gene analysis [34,35] and one by fine-mapping of a linkage signal [36]. GWA meta-analyses of T2DM and of T2DMrelated quantitative traits have resulted in identification of 38 T2DM susceptibility loci so far; most have been identified within the past 3 years [37-50]. The assembly of ever larger samples coupled with the increasing application of whole genome sequencing will probably identify additional susceptibility loci. However, even the currently known loci have illuminated new biology underlying T2DM, such as MTNR1B (encoding a member of the melatonin receptor family) $[45,46]$ and $C R Y 2$ (encoding a member of the cryptochrome family that regulates the clock gene) [49], which point to regulation of 'clock' genes and circadian rhythms as contributing to T2DM pathogenesis.

How has the discovery of T2DM susceptibility loci contributed to our understanding of the genetics of GDM? Two groups have examined whether T2DM susceptibility loci identified by GWA are also associated with GDM [51,52]. Cho et al. [52] examined 18 single nucleotide polymorphisms (SNPs) in nine T2DM susceptibility loci and tested them for association with GDM in a large 
case-control sample of Koreans. CDKAL1, encoding a protein of unknown function but having high sequence homology with proteins regulating cyclin-dependent kinase 5, and $C D K N 2 A$ and $C D K N 2 B$, two genes involved in cell cycle regulation, all showed strong evidence for association with GDM. Interestingly, the odds ratios for GDM were slightly higher (about 1.5 ) than the odds ratio of about 1.2 typically observed for T2DM. One possible reason for the larger effect size in this study may be the fact that the control group consisted of non-diabetic individuals of both sexes. Alternatively, these specific loci may make a larger contribution to the genetic risk for GDM than for T2DM. Other loci, HHEX (encoding a transcription factor involved in development of the ventral pancreas and possibly the liver), IGF2BP2 (encoding a protein that binds to the 5'-UTR of insulin-like growth factor- 2 mRNA and that may regulate translation), SLC30A8 (encoding a zinc transporter found on insulin secretory vesicles), and TCF7L2 (encoding a transcription factor), showed modest evidence for association with GDM, with $P$-values ranging between 0.038 and 0.003. The odds ratios for risk for GDM across these loci were similar to those observed for T2DM.

Similar to the study of Cho et al. [52], Lauenborg and colleagues [51] examined the association between 11 T2DM susceptibility loci for association with GDM in a Danish case-control sample. In their study [51], only TCF7L2 showed strong evidence for association with GDM, with an odds ratio similar to that observed for T2DM. Two additional loci, CDKAL1 and $H N F 1 B$ (encoding a member of the homeodomain-containing family of transcription factors), showed marginal association with GDM. They subsequently derived an allelic score for each individual by counting up the number of 'risk' alleles carried by each individual across the 11 loci and showed a difference in distribution of these allelic scores when comparing GDM with non-GDM women. Overall, they estimated the odds ratio for GDM to be 1.18 per allele in their sample after adjusting for age and BMI. Also, there was a 3.3-fold increased risk for GDM when they compared women carrying fewer than nine risk alleles with those carrying more than 15 risk alleles. Lauenborg et al. [51] then tested whether these 11 loci can be used to predict GDM by comparing various logisticregression-based models, assuming the 11 loci worked in an additive manner, and computing the receiver-operator curve (ROC) area under the curve (AUC) as a metric of accuracy. Age and BMI alone had an AUC of 0.68, suggesting a relatively poor ability to predict GDM. The 11 T2DM susceptibility loci had an AUC of 0.62, which was similar to the model with age and BMI alone. The AUC increased to 0.73 when the two were combined.

There are important points to be noted from the ROC results. First, not surprisingly, age and BMI alone are inadequate for discriminating GDM, suggesting that other clinical variables, such as the OGTT [4,53], may provide better discrimination. Second, many would view the near equivalent AUC between the non-genetic and genetic models as evidence for a lack of a genetic basis for GDM, but it should be noted that comparison across models used for ROC analysis cannot be used to assess whether a phenotype has a genetic basis or not. Furthermore, it is important to remember that these are known T2DM susceptibility loci and not necessarily susceptibility loci for GDM. Thus, there is no a priori reason that these loci should provide adequate discrimination of GDM. Finally, the genetic variants identified by GWA are only landmarks indicating the possible presence of a T2DM susceptibility variant. Additional work is necessary to identify the functional variant responsible for the increased T2DM risk and, once those variants are identified, it is possible the performance of genetic models may improve.

\section{Implications for family members}

The studies by Cho et al. [52] and Lauenborg et al. [51] suggest that GDM does not have a unique genetic predisposition and, at a minimum, that there is some overlap in genetic susceptibility to GDM and T2DM. This, of course, does not exclude the possibility that there are some loci uniquely contributing to the risk for GDM. The overlap in genetic susceptibility may partly explain the increased risk for T2DM in women with previous GDM [5-7]. Given this observation, an important question is what the implication is for family members of a woman with previous GDM.

There are precious few family-based studies of diabetes and even fewer studies examining critical diabetes phenotypes, given the shift to GWA studies based on case-control samples. Although there are family-based studies of T2DM in Hispanics [54-63], so far none are examining interactions among genes or with environmental exposures. Furthermore, only the Insulin Resistance Atherosclerosis Study Family Study [54] has direct measures of insulin resistance and insulin secretion, in their case based on frequently sampled intravenous glucose tolerance test (FSIGT) with Minimal Model analysis $[64,65]$. Other studies rely on indirect measures of these critical T2DM-related phenotypes. Furthermore, these family-based samples are ascertained on T2DM and not GDM.

The BetaGene study has hypothesized that genetic loci underlying susceptibility to GDM have implications for family members and has been studying the genetics underlying T2DM-related quantitative traits in Mexican American families of probands with or without a previous diagnosis of GDM [66-69]. BetaGene has two unique characteristics compared with other genetic 


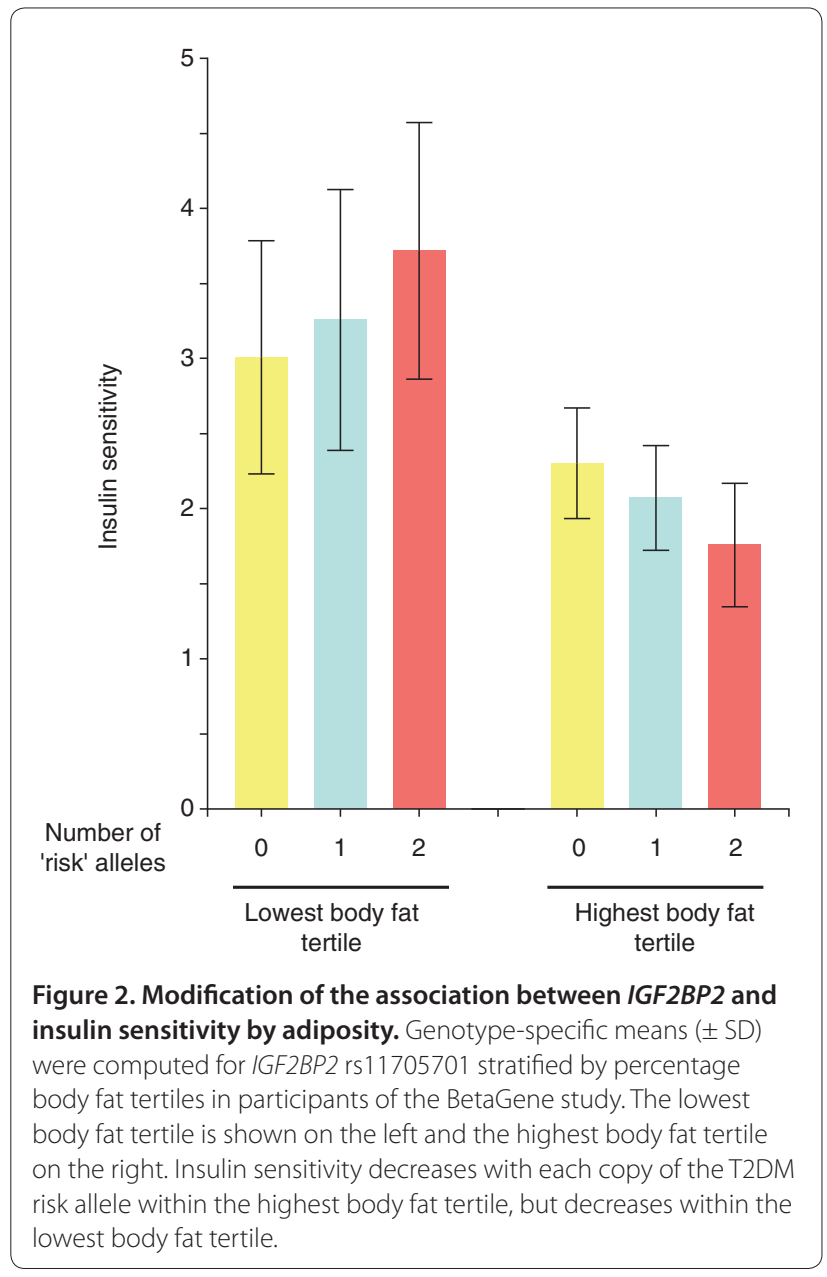

studies of diabetes. First, BetaGene is focusing on the analysis of T2DM-related quantitative traits, believing that understanding the biological effects of genetic variation may illuminate key components of the pathogenesis of GDM and T2DM. Second, a large subset of the BetaGene participants have undergone detailed phenotyping, including dual energy X-ray absorptiometry for body composition and FSIGT with Minimal Model analysis to estimate insulin sensitivity and insulin secretion, given the focus on quantitative traits. To my knowledge, BetaGene is the only family-based genetic study ascertained on GDM in the world, as of this writing.

The BetaGene study has shown associations between some T2DM susceptibility loci and T2DM-related quantitative traits $[66,68,69]$, but more importantly it has shown that these associations are modified by other factors, such as adiposity or other gene variants. For example, variation in TCF7L2 is one of the most highly replicated T2DM susceptibility loci. BetaGene was the first to show that variation in TCF7L2 was associated with GDM [66], an observation replicated by others [70]. BetaGene also showed that the association between TCF7L2 and
OGTT-based insulin secretion is modified by total body fat [66]. A similar modifying effect on the association between TCF7L2 and $\beta$-cell function as represented by the disposition index, a measure of $\beta$-cell function [65], was also observed. An interesting observation of this modifying effect of adiposity is that individuals carrying the T2DM 'risk' allele have a 'better' trait value than individuals carrying the 'non-risk' allele in the low body fat range, but this relationship flips in the high body fat range.

Figure 2 uses IGF2BP2 as an example of this phenomenon. This figure shows the IGF2BP2 genotype-specific insulin sensitivity (mean \pm standard deviation (SD)) in the lowest and highest tertiles of body fat in BetaGene participants [68]. Here, 'risk' allele refers to the allele conferring risk for T2DM as determined by the initial series of GWA studies [37-39]. Insulin sensitivity decreases with each copy of the T2DM risk allele within the highest body fat tertile, which ranged from $38.9 \%$ to $54 \%$ body fat. This is an expected pattern, given that insulin resistance is a hallmark of T2DM and one might expect that individuals carrying T2DM susceptibility variants might be insulin resistant compared with noncarriers. However, a counterintuitive pattern is observed within the lowest body fat tertile (range 8.7 to $31.7 \%$ body fat), where insulin sensitivity increases with each copy of the T2DM risk allele. This observation suggests a different biological effect of the T2DM 'risk' allele in the low compared with the high adiposity range.

The modifications of these genetic associations by adiposity can be viewed in two possible ways. One is that they represent potential gene-gene interactions, as GWA studies have identified loci underlying susceptibility to obesity and contributing to variation in obesity-related traits [71-78]. Here, body fat acts as a proxy for the effect of one or more of these variants. We have demonstrated examples of gene-gene interactions altering variation in T2DM-related quantitative traits in BetaGene [79,80]. A second perspective is that they represent the effect of environmental or lifestyle exposures. In this context, body fat could reflect net energy balance, such as the net caloric balance between dietary intake (quantity and composition) versus physical activity (type and intensity). Clearly, additional studies will be required to better understand this complex interaction.

\section{Clinical implications}

The Human Genome Project was initiated to decode the 'book of life' [81]. The idea that the genetic code for humans could be deciphered led to wide speculation about how such information could be used to improve human health, given the genetic predisposition of many common complex diseases. However, the initial results from GWA studies raised questions regarding the utility 
of genetic knowledge [82-84]. The currently known variants showing association with complex phenotypes, such as GDM or T2DM, account for a relatively small fraction of the known heritability, and this has raised questions about whether gene variants can be used for genetic prediction [84]. The study by Lauenborg et al. [51] and similar attempts to assess the predictive value of gene variants for T2DM $[85,86]$ support the notion that gene variants alone may not be useful as predictive tools. However, as noted above, genetic prediction models may improve once the functional variants are known, as suggested by a recent study of height by Yang and colleagues [87]. One area in which genetic information may be useful is with regard to family history, which is a strong clinical predictor for many complex diseases such as GDM and T2DM. In many cases, patients are unaware of their family history or have biased information about it. In this situation, susceptibility variants may provide an accurate reflection of the genetic burden carried by individuals and, in conjunction with other traditional clinical variables, may provide improved disease risk prediction.

Furthermore, the effect sizes of loci identified so far have been, for the most part, extremely small from a clinical or epidemiological perspective. Individual T2DM susceptibility loci have had estimated odds ratios for risk of T2DM less than 1.5 and the proportion of variance explained for T2DM-related quantitative traits has typically been less than $5 \%$, with similar results observed for GDM $[23,51,52,70]$ and related traits $[51,52,66-68,70]$. Skeptics have dismissed the practical utility of gene variants in the face of such small effect sizes. However, as elegantly noted by Hirschhorn [83], the goal of GWA studies and the identification of genetic loci conferring susceptibility to disease is not prediction of individual risk for disease, but biological discovery underlying the pathogenesis of these diseases. Indeed, one of the highlights of GWA studies, as noted above, is the discovery of the potential roles of MTNR1B and CRY2. MTNR1B was identified as contributing to T2DM susceptibility and variation in fasting glucose $[45,49]$ and variation in insulin secretion [88], whereas CRY2 contributes to variation in fasting glucose [49]. These loci highlight the potential importance of pathways related to 'clock' genes and circadian rhythms and their subsequent regulation of insulin secretion as contributing factors in the pathogenesis of T2DM.

Effect sizes of susceptibility loci should not be equated with biological relevance, as also noted by Hirschhorn [83]. Two specific examples can be gleaned from among the T2DM susceptibility loci. The E23K variant (rs5219) in KCNJ11, the ATP-sensitive $\mathrm{K}^{+}$channel of the pancreatic $\beta$-cell, is a T2DM susceptibility locus with an odds ratio of 1.18 [35]. KCNJ11 is the target of the sulfonylurea class of diabetes medications, highlighting the biological and clinical importance of this gene. The second example is the common Pro12Ala (rs1801282) variant in PPARG (peroxisome proliferator-activated receptor- $\gamma$, a nuclear transcription factor), which has an odds ratio of 1.27 for T2DM [34,89]. Thiazolidinediones are PPARG agonists that act as insulin-sensitizing agents and are used to treat T2DM. Studies also show that treating at-risk individuals with thiazolidinediones may be effective in significantly reducing, or possibly preventing, development of future T2DM [90-94]. Thus, one can confidently state that both KCNJ11 and PPARG have high biological relevance for the pathogenesis and treatment of T2DM.

The one area in which genetic variation may be best leveraged for clinical care purposes is pharmacogenetics. The response to a drug - whether in terms of efficacy of treatment or adverse effects - and dosing of medications are not likely to be adversely affected by environmental exposures and tend to have large effect sizes [95]. Therefore, some of the variability in response or dosing could be due to genetic variation. Pharmacogenetics in the area of diabetes is still in its infancy, although there have been studies examining $K C N J 11$ and sulfonylurea therapy for both rare $[96,97]$ and common $[98,99]$ variants and response to thiazolidinedione therapy and candidate genes [100-103]. Results from pharmacogenetic studies could potentially provide physicians with a powerful tool to adjust therapy appropriately for those individuals carrying variants known to affect a given medication. Distefano and Watanabe have recently reviewed the pharmacogenetics of diabetes [104].

Gene-gene and gene-environment interactions are also likely to be helpful to the clinician in making therapeutic decisions. The situation with IGF2BP2 is a good example in which a physician may choose to pay closer attention to the adiposity of carriers of the T2DM risk allele (Figure 2). Studies on the effects of physical activity on loci underlying susceptibility to obesity suggest similar clinical relevance when individuals whose genetic makeup is resistant to the effects of physical activity may require different interventions $[105,106]$.

\section{Conclusions}

The study of the genetics underlying GDM has significantly lagged behind that of other forms of diabetes. However, the dramatic gains made in understanding the genetic basis of both type 1 diabetes mellitus and T2DM in the past few years have important implications for GDM. Testing T2DM susceptibility loci in GDM casecontrol samples provides evidence suggesting that, at a minimum, GDM and T2DM share common susceptibility loci. Additional studies will be required to determine whether there are susceptibility loci unique to GDM. 
Loci that contribute to GDM are also likely to contribute to variation in GDM-related quantitative traits, which has implications for offspring. Thus, adverse fetal outcomes associated with GDM or hyperglycemia in general may also have a genetic basis, as evidenced by the interaction between maternal and fetal $G C K$ variants. Ultimately, a well-designed GWA or genome-wide sequencing study of GDM is needed to identify common variants of low effect and rare variants of large effect contributing to risk for GDM. In addition, there is increasing evidence that transcriptional regulation through chromatin modification, such as methylation, acetylation, and so on, may be an important contributor to disease risk. Genomic approaches to assessing chromatin modification are only now being applied to complex diseases and could provide additional insights into the genetic contribution to risk for GDM and fetal outcomes.

Identification of loci underlying GDM and GDMrelated traits will illuminate the biological basis for GDM susceptibility and provide important clues for improved interventions. However, such new biological insights will require additional detailed studies before they can be translated into the clinical setting. Thus, one cannot expect rapid bench-to-bedside translation of genetic findings. However, current medical training is paying insufficient attention to the coming transformative effect of genetic knowledge. Individualized medicine has not yet arrived and may never become a reality to the extent that has been previously hyped in the media. However, generalized gene-based response profiles to both lifestyle and pharmacological interventions may become a regular part of a physician's arsenal to improve clinical care.

\section{Abbreviations \\ AUC, area under the curve; BMI, body mass index; CDKAL1, CDK5 regulatory subunit associated protein 1-like 1; CRY2, cryptochrome 2 (photolyase- like); FSIGT, frequently sampled intravenous glucose tolerance test; GCK, glucokinase; GDM, gestational diabetes mellitus; GWA, genome-wide association; HAPO, Hyperglycemia and Adverse Pregnancy Outcome; IGF2BP2, insulin-like growth factor 2 mRNA binding protein 2; KCNJ11, potassium inwardly rectifying channel, subfamily J, member 11; MODY2, maturity- onset diabetes of the young 2; MTNR1B, melatonin receptor 1B; OGTT, oral glucose tolerance test; PPARG, peroxisome proliferator-activated receptor- $\gamma$; ROC, receiver-operator curve; SD, standard deviation; T2DM, type 2 diabetes mellitus; TCF7L2, transcription factor 7-like 2.}

\section{Competing interests}

RMW has been a consultant for Merck \& Co and Vivus Inc. Takeda Pharmaceuticals North America provides him with pioglitazone tablets for a pharmacogenetics study of pioglitazone monotherapy. He is partly supported by an investigator-initiated research grant from Merck \& Co (number 32983).

\section{Acknowledgements}

I gratefully acknowledge the contributions made by my colleagues in the FUSION and BetaGene studies, as well as my colleagues in the MAGIC, DIAGRAM+, and GIANT consortia that are highlighted in this review.

Published: 25 March 2011
References

1. Engelgau MM, Herman WH, Smith PJ, German RR, Aubert RE: The epidemiology of diabetes and pregnancy in the U.S., 1988. Diabetes Care 1995, 18:1029-1033.

2. Ferrara A: Increasing prevalence of gestational diabetes mellitus: a public health perspective. Diabetes Care 2007, 30 Suppl 2:S141-S146.

3. Dabelea D, Snell-Bergeon JK, Hartsfield CL, Bischoff KJ, Hamman RF, McDuffie RS: Increasing prevalence of gestational diabetes mellitus (GDM) over time and by birth cohort: Kaiser Permanente of Colorado GDM Screening Program. Diabetes Care 2005, 28:579-584.

4. Metzger BE: Summary and recommendation of the Third International Workshop-Conference on Gestational Diabetes Mellitus. Diabetes 1991, 40:197-201.

5. O'Sullivan JB: Diabetes mellitus after GDM. Diabetes 1991, 40 Suppl 2:131-135.

6. Kjos SL, Peters RK, Xiang A, Henry OA, Montoro M, Buchanan TA: Predicting future diabetes in Latino women with gestational diabetes. Diabetes 1995 44:586-591.

7. Kim C, Newton KM, Knopp RH: Gestational diabetes and the incidence of type 2 diabetes. Diabetes Care 2002, 25:1862-1868.

8. Johns K, Olynik C, Mase R, Kreisman S, Tildesley H: Gestational diabetes mellitus outcome in 394 patients. J Obstet Gynaecol Can 2006, 28:122-127.

9. Boulet SL, Alexander GR, Salihu HM, Pass M: Macrosomic births in the United States: determinants, outcomes, and proposed grades of risk. Am J Obstet Gynecol 2003, 188:1372-1378.

10. Esakoff TF, Cheng YW, Sparks TN, Caughey AB: The association between birthweight $4000 \mathrm{~g}$ or greater and perinatal outcomes in patients with and without gestational diabetes mellitus. Am J Obstet Gynecol 2009, 200:672-674

11. Pettitt DJ, Knowler WC, Baird HR, Bennett PH: Gestational diabetes: infant and maternal complications of pregnancy in relation to third-trimester glucose tolerance in the Pima Indians. Diabetes Care 1980, 3:458-464

12. Pettitt DJ, Knowler WC: Long-term effects of the intrauterine environment birth weight, and breast-feeding in Pima Indians. Diabetes Care 1998, 21 Suppl 2:B138-B141.

13. Dabelea D, Hanson RL, Lindsay RS, Pettitt DJ, Imperatore G, Gabir MM, Roumain J, Bennett PH, Knowler WC: Intrauterine exposure to diabetes conveys risks for type 2 diabetes and obesity: a study of discordant sibships. Diabetes 2000, 49:2208-2211.

14. HAPO Study Cooperative Research Group: The Hyperglycemia and Adverse Pregnancy Outcome (HAPO) Study. Int J Gynaecol Obstet 2002, 78:69-77.

15. Leary J, Pettitt DJ, Jovanovic L: Gestational diabetes guidelines in a HAPO world. Best Pract Res Clin Endocrinol Metab 2010, 24:673-685.

16. HAPO Study Cooperative Research Group: Hyperglycaemia and Adverse Pregnancy Outcome (HAPO) Study: associations with maternal body mass index. BJOG 2010, 117:575-584.

17. National Diabetes Data Group: Classification and diagnosis of diabetes mellitus and other categories of glucose intolerance. Diabetes 1979, 28:1039-1057.

18. World Health Organization: Diabetes Mellitus: Report of a WHO Study Group. Geneva: World Health Organization; 1985.

19. The Expert Committee on the Diagnosis and Classification of Diabetes Mellitus: Report of the expert committee on the diagnosis and classification of diabetes mellitus. Diabetes Care 1997, 20:1183-1197.

20. World Health Organization: Definition, Diagnosis and Classification of Diabetes Mellitus and its Complications. Report of a WHO Consultation. Geneva: World Health Organization; 1999.

21. McLellan JA, Barrow BA, Levy JC, Hammersley MS, Hattersley AT, Gillmer MD, Turner RC: Prevalence of diabetes mellitus and impaired glucose tolerance in parents of women with gestational diabetes. Diabetologia 1995, 38:693-698.

22. Martin AO, Simpson JL, Ober C, Freinkel N: Frequency of diabetes mellitus in mothers of probands with gestational diabetes: possible maternal influence on the predisposition to gestational diabetes. Am J Obstet Gynecol 1985, 151:471-475.

23. Watanabe $\mathrm{RM}$, Black MH, Xiang AH, Allayee $H$, Lawrence JM, Buchanan TA Genetics of gestational diabetes mellitus and type 2 diabetes. Diabetes Care 2007, 30:S134-S140

24. Robitaille J, Grant AM: The genetics of gestational diabetes mellitus: evidence for relationship with type 2 diabetes mellitus. Genet Med 2008, 10:240-250. 
25. Vionnet N, Stoffel M, Takeda J, Yasuda K, Bell Gl, Zouali H, Lesage S, Velho G, Iris F, Passa P, et al:: Nonsense mutation in the glucokinase gene causes early-onset non-insulin-dependent diabetes mellitus. Nature 1992, 356:721-722.

26. Stoffel M, Froguel Ph, Takeda J, Zouali H, Vionnet N, Nishi S, Weber IT, Harrison RW, Pilkis SJ, Lesage S, Vaxillaire M, Velho G, Sun F, Iris F, Passa Ph, Cohen D, Bell Gl: Human glucokinase gene: Isolation, characterization, and identification of two missense mutations linked to early-onset noninsulin-dependent (type 2) diabetes mellitus. Proc Natl Acad Sci U S A 1992, 89:7698-7702

27. Byrne MM, Sturis J, Clement K, Vionnet N, Pueyo ME, Stoffel M, Takeda J, Passa P, Cohen D, Bell Gl, Velho G, Froguel P, Polonsky KS: Insulin secretory abnormalities in subjects with hyperglycemia due to glucokinase mutations. J Clin Invest 1994, 93:1120-1130.

28. Hattersley AT, Turner RC, Permutt MA, Patel P, Tanizawa Y, Chiu KC, O'Rahilly S, Watkins PJ, Wainscoat JS: Linkage of type 2 diabetes to the glucokinase gene. Lancet 1992, 339:1307-1310.

29. Stoffel M, Bell KL, Blackburn CL, Powerll KL, Seo TS, Takeda J, Vionnet N, Xiang $\mathrm{KS}$, Gidh-Jain M, Pilkis SJ: Identification of glucokinase mutations in subjects with gestational diabetes mellitus. Diabetes 1993, 42:937-940.

30. Hattersley AT, Tooke JE: The fetal insulin hypothesis: an alternative explanation of the association of low birthweight with diabetes and vascular disease. Lancet 1999, 353:1789-1792.

31. Hattersley AT, Beards F, Ballantyne E, Appleton M, Harvey R, Ellard S. Mutations in the glucokinase gene of the fetus result in reduced birth weight. Nat Genet 1998, 19:268-270.

32. Weedon MN, Frayling TM, Shields B, Knight B, Turner T, Metcalf BS, Voss $L$, Wilkin TJ, Mccarthy A, Ben-Shlomo Y, Davey-Smith G, Ring S, Jones R, Golding J, Byberg L, Mann V, Axelsson T, Syvänen AC, Leon D, Hattersley AT: Genetic regulation of birth weight and fasting glucose by a common polymorphism in the islet promoter of the glucokinase gene. Diabetes 2005, 54:576-581.

33. Weedon MN, Clark VJ, Qian Y, Ben-Shlomo Y, Timpson N, Ebrahim S, Lawlor DA, Pembrey ME, Ring S, Wilkin TJ, Voss LD, Jeffery AN, Metcalf B, Ferrucci L, Corsi AM, Murray A, Melzer D, Knight B, Shields B, Davey Smith G, Hattersley AT, Di Rienzo A, Frayling TM: A common haplotype of the glucokinase gene alters fasting glucose and birth weight: association in six studies and population-genetics analyses. Am J Hum Genet 2006, 79:991-1001.

34. Deeb SS, Fajas L, Nemoto M, Pihlajamäki J, Laakso M, Fujimoto W, Auwerx J: A Pro12Ala substitution in PPARg2 associated with decreased receptor activity, lower body mass index and improved insulin sensitivity. Nat Genet 1998, 20:284-287.

35. Gloyn AL, Weedon MN, Owen KR, Turner MJ, Knight BA, Hitman G, Walker M, Levy JC, Sampson M, Halford S, McCarthy MI, Hattersley AT, Frayling TM: Large-scale association studies of variants in genes encoding the pancreatic b-cell $\mathrm{K}_{\text {APP }}$ channel subunits Kir6.2 (KCNJ11) and SUR1 (ABCC8) confirm that the KCNJ11 E23K variant is associated with type 2 diabetes. Diabetes 2003, 52:568-572

36. Grant SF, Thorleifsson G, Reynisdottir I, Benediktsson R, Manolescu A, Sainz J, Helgason A, Stefansson H, Emilsson V, Helgadottir A, Styrkarsdottir U, Magnusson KP, Walters GB, Palsdottir E, Jonsdottir T, Gudmundsdottir T, Gylfason A, Saemundsdottir J, Wilensky RL, Reilly MP, Rader DJ, Bagger Y, Christiansen C, Gudnason V Sigurdsson G, Thorsteinsdottir U, Gulcher JR, Kong A, Stefansson K: Variant of transcription factor 7-like 2 (TCF7L2) gene confers risk of type 2 diabetes. Nat Genet 2006, 38:320-323.

37. Diabetes Genetics Initiative of Broad Institute of Harvard and MIT, Lund University, and Novartis Institutes of BioMedical Research, Saxena R, Voight BF, Lyssenko V, Burtt NP, de Bakker PI, Chen H, Roix JJ, Kathiresan S, Hirschhorn JN, Daly MJ, Hughes TE, Groop L, Altshuler D, Almgren P, Florez JC, Meyer J, Ardlie K, Bengtsson Boström K, Isomaa B, Lettre G, Lindblad U, Lyon HN, Melander O, Newton-Cheh C, Nilsson P, Orho-Melander M, Råstam L, Speliotes EK, Taskinen MR, et al:: Genome-wide association analysis identifies loci for type 2 diabetes and triglyceride levels. Science 2007, 316:1331-1336.

38. Scott LJ, Mohlke KL, Bonnycastle LL, Willer CJ, Li Y, Duren WL, Erdos MR, Stringham HM, Chines PS, Jackson AU, Prokunina-Olsson L, Ding C-J, Swift AJ, Narisu N, Hu T, Pruim R, Xiao R, Li X-Y, Conneally PM, Riebow NL, Sprau AG, Tong M, White PP, Hetrick KN, Barnhart MW, Bark CW, Goldstein JL, Watkins L, Xiang F, Saramies J, et al:: A genome-wide association study of type 2 diabetes in Finns detects multiple susceptibility variants. Science 2007, 316:1341-1345.
39. Zeggini E, Weedon MN, Lindgren CM, Frayling TM, Elliott KS, Lango $H$, Timpson NJ, Perry JRB, Rayner NW, Freathy RM, Barrett JC, Shields B, Morris AP, Ellard S, Groves CJ, Harries LW, Marchini JL, Owen KR, Knight B, Cardon LR, Walker M, Hitman GA, Morris AD, Doney ASF, The Wellcome Trust Case Control Consortium, McCarthy MI, Hattersley AT: Replication of genomewide association signals in U.K. samples reveals risk loci for type 2 diabetes. Science 2007, 316:1336-1341.

40. Sladek R, Rocheleau G, Rung J, Dina C, Shen L, Serre D, Boutin P, Vincent D, Belisle A, Hadjadj S, Balkau B, Heude B, Charpentier G, Hudson TJ, Montpetit A, Pshezhetsky AV, Prentki M, Posner Bl, Balding DJ, Meyre D, Polychronakos C, Froguel P: A genome-wide association study identified novel risk loci for type 2 diabetes. Nature 2007, 445:881-885.

41. Steinthorsdottir $V$, Thorleifsson G, Reynisdottir I, Benediktsson R, Jonsdottir T, Walters GB, Styrkarsdottir U, Gretarsdottir S, Emilsson V, Ghosh S, Baker A Snorradottir S, Bjarnason H, Ng MCY, Hansen T, Bagger Y, Wilensky RL, Reilly MP, Adeyemo A, Chen Y, Zhou J, Gudnason V, Chen G, Huang H, Lashley K, Doumatey A, So W-Y, Ma RCY, Andersen G, Borch-Johnsen K, et al:: A variant in CDKAL1 influences insulin response and risk of type 2 diabetes. Nat Genet 2007, 39:770-775.

42. Zeggini E, Scott $\sqcup$, Saxena R, Voight BF, Diabetes Genetics Replication and Meta-analysis (DIAGRAM) Consortium: Meta-analysis of genome-wide association data and large-scale replication identifies additional susceptibility loci for type 2 diabetes. Nat Genet 2008, 40:638-645.

43. Yasuda K, Miyake K, Horikawa Y, Hara K, Osawa H, Furuta H, Hirota Y, Mori H, Jonsson A, Sato Y, Yamagata K, Hinokio Y, Wang HY, Tanahashi T, Nakamura N, Oka Y, I wasaki N, Iwamoto Y, Yamada Y, Seino Y, Maegawa H, Kashiwagi A, Takeda J, Maeda E, Shin HD, Cho YM, Park KS, Lee HK, Ng MC, Ma RC, et al:: Variants in KCNQ1 are associated with susceptibility to type 2 diabetes mellitus. Nat Genet 2008, 40:1092-1097.44. Unoki H, Takahashi A, Kawaguchi T, Hara K, Horikoshi M, Andersen G, Ng DP, Holmkvist J, BorchJohnsen K, Jorgensen T, Sandbaek A, Lauritzen T, Hansen T, Nurbaya S, Tsunoda T, Kubo M, Babazono T, Hirose H, Hayashi M, Iwamoto Y, Kashiwagi A, Kaku K, Kawamori R, Tai ES, Pedersen O, Kamatani N, Kadowaki T, Kikkawa R, Nakamura Y, Maeda S: SNPs in KCNQ1 are associated with susceptibility to type 2 diabetes in East Asian and European populations. Nat Genet 2008, 40:1098-1102.

45. Bouatia-Naji N, Bonnefond A, Cavalcanti-Proenca C, Sparso T, Holmkvist J, Marchand M, Delplanque J, Lobbens S, Rocheleau G, Durand E, De GF, Chevre JC, Borch-Johnsen K, Hartikainen AL, Ruokonen A, Tichet J, Marre M, Weill J, Heude B, Tauber M, Lemaire K, Schuit F, Elliott P, Jorgensen T, Charpentier G, Hadjadj S, Cauchi S, Vaxillaire M, Sladek R, Visvikis-Siest S, et al:: A variant near MTNR1B is associated with increased fasting plasma glucose levels and type 2 diabetes risk. Nat Genet 2009, 41:89-94.

46. Prokopenko I, Langenberg C, Florez JC, Saxena R, Soranzo N, Thorleifsson G, Loos RJ, Manning AK, Jackson AU, Aulchenko Y, Potter SC, Erdos MR, Sanna S, Hottenga JJ, Wheeler E, Kaakinen M, Lyssenko V, Chen WM, Ahmadi K, Beckmann JS, Bergman RN, Bochud M, Bonnycastle LL, Buchanan TA, Cao A, Cervino A, Coin L, Collins FS, Crisponi L, de Geus EJ, et al:: Variants in MTNR1B influence fasting glucose levels. Nat Genet 2009, 41:77-81.

47. Rung J, Cauchi S, Albrechtsen A, Shen L, Rocheleau G, Cavalcanti-Proenca C, Bacot F, Balkau B, Belisle A, Borch-Johnsen K, Charpentier G, Dina C, Durand E, Elliott P, Hadjadj S, Jarvelin MR, Laitinen J, Lauritzen T, Marre M, Mazur A, Meyre D, Montpetit A, Pisinger C, Posner B, Poulsen P, Pouta A, Prentki M, Ribel-Madsen R, Ruokonen A, Sandbaek A, et al:: Genetic variant near IRS1 is associated with type 2 diabetes, insulin resistance and hyperinsulinemia. Nat Genet 2009, 41:1110-1115.

48. Saxena R, Hivert MF, Langenberg C, Tanaka T, Pankow JS, Vollenweider P, Lyssenko V, Bouatia-Naji N, Dupuis J, Jackson AU, Kao WH, Li M, Glazer NL, Manning AK, Luan J, Stringham HM, Prokopenko I, Johnson T, Grarup N, Boesgaard TW, Lecoeur C, Shrader P, O'Connell J, Ingelsson E, Couper DJ, Rice K, Song K, Andreasen CH, Dina C, Kottgen A, et al:: Genetic variation in GIPR influences the glucose and insulin responses to an oral glucose challenge. Nat Genet 2010, 42:142-148.

49. Dupuis J, Langenberg C, Prokopenko I, Saxena R, Soranzo N, Jackson AU, Wheeler E, Glazer NL, Bouatia-Naji N, Gloyn AL, Lindgren CM, Magi R, Morris AP, Randall J, Johnson T, Elliott P, Rybin D, Thorleifsson G, Steinthorsdottir V, Henneman P, Grallert H, Dehghan A, Hottenga JJ, Franklin CS, Navarro P, Song K, Goel A, Perry JR, Egan JM, Lajunen T, et al.: New genetic loci implicated in fasting glucose homeostasis and their impact on type 2 diabetes risk. Nat Genet 2010, 42:105-116

50. Voight BF, Scott LJ, Steinthorsdottir V, Morris AP, Dina C, Welch RP, Zeggini E, 
Huth C, Aulchenko YS, Thorleifsson G, McCulloch L, Ferreira T, Grallert H Amin N, Wu G, Willer CJ, Raychaudhuri S, McCarroll SA, Langenberg C, Hofmann OM, Dupuis J, Qi L, Segrè AV, van Hoek M, Navarro P, Ardlie K, Balkau B, Benediktsson R, Bennett AJ, Blagieva R, et al:: Twelve type 2 diabetes susceptiblity loci identified through large-scale association analysis. Nat Genet 2010, 42:579-589.

51. Lauenborg J, Grarup N, Damm P, Borch-Johnsen K, Jørgensen T, Pedersen O, Hansen T: Common type 2 diabetes risk gene variants asociated with gestational diabetes. J Clin Endocrinol Metab 2009, 94:145-150.

52. Cho YM, Kim TH, Lim S, Choi SH, Shin HD, Lee HK, Park KS, Jang HC: Type 2 diabetes-associated genetic variants discovered in the recent genomewide association studies are related to gestational diabetes mellitus in the Korean population. Diabetologia 2009, 52:253-261.

53. van $L M$, Zweers EJ, Opmeer BC, van BE, ter Brugge HG, de Valk HW, Mol BW, Visser GH: Comparison of accuracy measures of two screening tests for gestational diabetes mellitus. Diabetes Care 2007, 30:2779-2784.

54. Henkin L, Bergman RN, Bowden DW, Ellsworth DL, Haffner SM, Langefeld CD, Mitchell BD, Norris JM, Rewers M, Saad MF, Stamm E, Wagenknecht LE, Rich SS: Genetic epidemiology of insulin resistance and visceral adiposity: the IRAS family study design and methods. Am J Epidemiol 2003, 13:211-217.

55. Palmer ND, Goodarzi MO, Langefeld CD, Ziegler J, Norris JM, Haffner SM, Bryer-Ash M, Bergman RN, Wagenknecht LE, Taylor KD, Rotter Jl, Bowden DW: Quantitative trait analysis of type 2 diabetes susceptibility loci identified from whole genome association studies in the Insulin Resistance Atherosclerosis Family Study. Diabetes 2008, 57:1093-1100

56. Norris JM, Langefeld CD, Talbert ME, Wing MR, Haritunians $T$, Fingerlin $T E$, Hanley AJ, Ziegler JT, Taylor KD, Haffner SM, Chen YD, Bowden DW, Wagenknecht LE: Genome-wide association study and follow-up analysis of adiposity traits in Hispanic Americans: the IRAS Family Study. Obesity (Silver Spring) 2009, 17:1932-1941.

57. Rich SS, Goodarzi MO, Palmer ND, Langefeld CD, Ziegler J, Haffner SM, BryerAsh M, Norris JM, Taylor KD, Haritunians T, Rotter Jl, Chen YD, Wagenknecht $L E$, Bowden DW, Bergman RN: A genome-wide association scan for acute insulin response to glucose in Hispanic-Americans: the Insulin Resistance Atherosclerosis Family Study (IRAS FS). Diabetologia 2009, 52:1326-1333.

58. Lehman DM, Richardson DK, Jenkinson CP, Hunt KJ, Dyer TD, Leach RJ, Arya R, Abboud HE, Blangero J, Duggirala R, Stern MP: P2 promoter variants of the hepatocyte nuclear factor 4alpha gene are associated with type 2 diabetes in Mexican Americans. Diabetes 2007, 56:513-517.

59. Lehman DM, Hunt KJ, Leach RJ, Hamlington J, Arya R, Abboud HE, Duggirala R, Blangero J, Goring HH, Stern MP: Haplotypes of transcription factor 7-like 2 (TCF7L2) gene and its upstream region are associated with type 2 diabetes and age of onset in Mexican Americans. Diabetes 2007, 56:389-393.

60. Thameem F, Puppala S, Arar NH, Stern MP, Blangero J, Duggirala R, Abboud HE: Endothelial nitric oxide synthase (eNOS) gene polymorphisms and their association with type 2 diabetes-related traits in Mexican Americans. Diab Vasc Dis Res 2008, 5:109-113.

61. Jenkinson CP, Coletta DK, Flechtner-Mors M, Hu SL, Fourcaudot MJ, Rodriguez LM, Schneider J, Arya R, Stern MP, Blangero J, Duggirala R, DeFronzo RA: Association of genetic variation in ENPP1 with obesity-related phenotypes. Obesity (Silver Spring) 2008, 16:1708-1713.

62. Thameem F, Puppala S, Arar N, Blangero J, Stern MP, Duggirala R, Abboud HE: Genetic polymorphisms in the renin-angiotensin system (RAS) genes and their association analysis with type 2 diabetes and related traits in Mexican Americans. Diabetes Res Clin Pract 2008, 79:e14-e16.

63. Thameem F, Puppala S, He X, Arar NH, Stern MP, Blangero J, Duggirala R, Abboud HE: Evaluation of gremlin 1 (GREM1) as a candidate susceptibility gene for albuminuria-related traits in Mexican Americans with type 2 diabetes mellitus. Metabolism 2009, 58:1496-1502.

64. Bergman RN, Ider YZ, Bowden CR, Cobelli C: Quantitative estimation of insulin sensitivity. Am J Physiol 1979, 236:E667-E677.

65. Bergman RN, Phillips LS, Cobelli C: Physiologic evaluation of factors controlling glucose tolerance in man. Measurement of insulin sensitivity and b-cell glucose sensitivity from the response to intravenous glucose. J Clin Invest 1981, 68:1456-1467.

66. Watanabe RM, Allayee H, Xiang AH, Trigo E, Hartiala J, Lawrence JM Buchanan TA: Transcription factor 7-like 2 (TCF7L2) is associated with gestational diabetes mellitus and interacts with adiposity to alter insulin secretion in Mexican Americans. Diabetes 2007, 56:1481-1485.

67. Bottini N, Allayee H, Shu Y-H, Xiang AH, Trigo E, Hartiala J, Lawrence JM,
Buchanan TA, Watanabe RM: Genetic variation in acid phosphatase 1 (ACP1) is associated with insulin resistance in Mexican American families of a proband with gestational diabetes mellitus (GDM) [abstract]. Diabetes 2007, 56:A490.

68. Li X, Allayee H, Xiang AH, Trigo E, Hartiala J, Lawrence JM, Buchanan TA, Watanabe RM: Variation in IGF2BP2 interacts with adiposity to alter insulin sensitivity in Mexican Americans. Obesity 2009, 17:729-736.

69. Shu Y-H, Li X, Xiang AH, Trigo E, Kuusisto J, Hartiala J, Swift AJ, Kawakubo M, Stringham HM, Bonnycastle LL, Lawrence JM, Laakso M, Allayee H, Buchanan TA, Watanabe RM: Effect of variation in glucokinase (GCK) and glucose-6phosphatase catalytic subunit 2 (G6PC2) on fasting glucose is additive, but determined by their differential effects on insulin secretion [abstract]. Diabetes 2009, 58:A84.

70. Shaat N, Lernmark A, Karlsson E, Ivarsson S, Parikh H, Berntorp K, Groop L: A variant in the transciprtion factor 7-like 2 (TCF7L2) gene is associated with an increased risk of gestational diabetes mellitus. Diabetologia 2007, 50:972-979.

71. Frayling TM, Timpson NJ, Weedon MN, Zeggini E, Freathy RM, Lindgren CM, Perry JRB, Elliott KS, Lango H, Rayner NW, Shields B, Harries LW, Barrett JC, Ellard S, Groves CJ, Knight B, Patch A-M, Ness AR, Ebrahim S, Lawlor DA, Ring SM, Ben-Shlomo Y, Jarvelin M-R, Sovio U, Bennett AJ, Melzer D, Ferrucci L, Loos RJF, Barroso I, Wareham NJ, et al:: A common variant in the FTO gene is associated with body mass index and predisposes to childhood and adult obesity. Science 2007, 316:889-894.

72. Loos RJ, Lindgren CM, Li S, Wheeler E, Zhao JH, Prokopenko I, Inouye M, Freathy RM, Attwood AP, Beckmann JS, Berndt SI, Jacobs KB, Chanock SJ, Hayes RB, Bergmann S, Bennett AJ, Bingham SA, Bochud M, Brown M, Cauchi S, Connell JM, Cooper C, Smith GD, Day I, Dina C, De S, Dermitzakis ET, Doney AS, Elliott KS, Elliott P, et al:: Common variants near MC4R are associated with fat mass, weight and risk of obesity. Nat Genet 2008, 40:768-775.

73. Chambers JC, Elliott P, Zabaneh D, Zhang W, Li Y, Froguel P, Balding D, Scott J, Kooner JS: Common genetic variation near MC4R is associated with waist circumference and insulin resistance. Nat Genet 2008, 40:716-718.

74. Willer CJ, Speliotes EK, Loos RJ, Li S, Lindgren CM, Heid IM, Berndt SI, Elliott AL, Jackson AU, Lamina C, Lettre G, Lim N, Lyon HN, McCarroll SA, Papadakis K, O L. Randall JC, Roccasecca RM, Sanna S, Scheet P. Weedon MN, Wheeler E, Zhao JH, Jacobs LC, Prokopenko I, Soranzo N, Tanaka T, Timpson NJ, Almgren $P$, Bennett A, et al: Six new loci associated with body mass index highlight a neuronal influence on body weight regulation. Nat Genet 2009, 41:25-34

75. Thorleifsson G, Walters GB, Gudbjartsson DF, Steinthorsdottir V, Sulem P, Helgadottir A, Styrkarsdottir U, Gretarsdottir S, Thorlacius S, Jonsdottir I, Jonsdottir T, Olafsdottir EJ Olafsdottir GH, Jonsson T, Jonsson F BorchJohnsen K, Hansen T, Andersen G, Jorgensen T, Lauritzen T, Aben KK, Verbeek AL, Roeleveld N, Kampman E, Yanek LR, Becker LC, Tryggvadottir L, Rafnar T, Becker DM, Gulcher J, et al: Genome-wide association yields new sequence variants at seven loci that associate with measures of obesity. Nat Genet 2009, 41:18-24

76. Lindgren CM, Heid IM, Randall JC, Lamina C, Steinthorsdottir V, Qi L, Speliotes EK, Thorleifsson G, Willer CJ, Herrera BM, Jackson AU, Lim N, Scheet P, Soranzo $\mathrm{N}$, Amin N, Aulchenko YS, Chambers JC, Drong A, Luan J, Lyon HN, Rivadeneira F, Sanna S, Timpson NJ Zillikens MC, Zhao JH, Almgren P. Bandinelli S, Bennett AJ, Bergman RN, Bonnycastle LL, et al:: Genome-wide association scan meta-analysis identifies three loci influencing adiposity and fat distribution. PLoS Genet 2009, 5:e1000508.

77. Speliotes EK, Willer CJ, Berndt SI, Monda KL, Thorleifsson G, Jackson AU, Allen HL, Lindgren CM, Luan J, Magi R, Randall JC, Vedantam S, Winkler TW, Qi L, Workalemahu T, Heid IM, Steinthorsdottir V, Stringham HM, Weedon MN Wheeler E, Wood AR, Ferreira T, Weyant RJ, Segre AV, Estrada K, Liang L, Nemesh J, Park JH, Gustafsson S, Kilpelainen TO, et al:: Association analyses of 249,796 individuals reveal 18 new loci associated with body mass index. Nat Genet 2010, 42:948

78. Heid IM, Jackson AU, Randall JC, Winkler TW, Qi L Steinthorsdottir V, Thorleifsson G, Zillikens MC, Speliotes EK, Magi R, Workalemahu T, White CC, Bouatia-Naji N, Harris TB, Berndt SI, Ingelsson E, Willer CJ, Weedon MN, Luan J, Vedantam S, Esko T, Kilpelainen TO, Kutalik Z, Li S, Monda KL, Dixon AL, Holmes CC, Kaplan LM, Liang L, Min JL, et al: Meta-analysis identifies 13 new loci associated with waist-hip ratio and reveals sexual dimorphism in the genetic basis of fat distribution. Nat Genet 2010, 42:960.

79. Black MH, Fingerlin TE, Allayee $H$, Zhang W, Xiang AH, Trigo E, Hartiala J, Lehtinen AB, Haffner SM, Bergman RN, McEachin RC, Kjos SL, Lawrence JM, Buchanan TA, Watanabe RM: Evidence of interaction between peroxisome 
proliferator-activated receptor-g2 and hepatocyte nuclear factor-4a contributing to variation in insulin sensitivity in Mexican Americans. Diabetes 2008, 57:1048-1056.

80. Li X, Shu YH, Xiang AH, Trigo E, Kuusisto J, Hartiala J, Swift AJ, Kawakubo M, Stringham HM, Bonnycastle LL, Lawrence JM, Laakso M, Allayee H, Buchanan TA, Watanabe RM: Additive effects of genetic variation in GCK and G6PC2 on insulin secretion and fasting glucose. Diabetes 2009, 58:2946-2953.

81. Schuler GD, Boguski MS, Stewart EA, Stein LD, Gyapay G, Rice K, White RE, Rodriguez-Tome P, Aggarwal A, Bajorek E, Bentolila S, Birren BB, Butler A, Castle AB, Chiannilkulchai N, Chu A, Clee C, Cowles S, Day PJ, Dibling T, Drouot N, Dunham I, Duprat S, East C, Hudson TJ: A gene map of the human genome. Science 1996, 274:540-546

82. Goldstein DB: Common genetic variation and human traits. N Eng/J Med 2009, 360:1696-1698.

83. Hirschhorn JN: Genomewide association studies - illuminating biologic pathways. NEngl J Med 2009, 360:1699-1701.

84. Kraft P, Hunter DJ: Genetic risk prediction - are we there yet? N Engl J Med 2009, 360:1701-1703.

85. van Hoek M, Dehghan A, Witteman JC, Van Duijn CM, Uitterlinden AG, Oostra BA, Hofman A, Sijbrands EJ, Janssens AC: Predicting type 2 diabetes based on polymorphisms from genome-wide association studies: a populationbased study. Diabetes 2008, 57:3122-3128.

86. Lango H, Palmer CN, Morris AD, Zeggini E, Hattersley AT, McCarthy MI, Frayling TM, Weedon MN: Assessing the combined impact of 18 common genetic variants of modest effect sizes on type 2 diabetes risk. Diabetes 2008, 57:3129-3135.

87. Yang J, Benyamin B, McEvoy BP, Gordon S, Henders AK, Nyholt DR, Madden PA, Heath AC, Martin NG, Montgomery GW, Goddard ME, Visscher PM: Common SNPs explain a large proportion of the heritability for human height. Nat Genet 2010, 42:565-569.

88. Lyssenko V, Nagorny CL, Erdos MR, Wierup N, Jonsson A, Spegel P, Bugliani M, Saxena R, Fex M, Pulizzi N, Isomaa B, Tuomi T, Nilsson P, Kuusisto J, Tuomilehto J, Boehnke M, Altshuler D, Sundler F, Eriksson JG, Jackson AU, Laakso M, Marchetti P, Watanabe RM, Mulder H, Groop L: Common variant in MTNR1B associated with increased risk of type 2 diabetes and impaired early insulin secretion. Nat Genet 2009, 41:82-88.

89. Altshuler D, Hirschhorn JN, Klannemark M, Lindgren CM, Vohl M-C, Nemesh J, Lane CR, Schaffner SF, Bolk S, Brewer C, Tuomi T, Gaudet D, Hudson TJ, Daly M, Groop L, Lander ES: The common PPARg Pro12Ala polymorphism is associated with decreased risk of type 2 diabetes. Nat Genet 2000, 26:76-80.

90. Antonucci T, Whitcomb R, McLain R, Lockwood D: Impaired glucose tolerance is normalized by treatment with the thiazolidinedione troglitazone. Diabetes Care 1997, 20:188-193.

91. Buchanan TA, Xiang AH, Peters RK, Kjos SL, Marroquin A, Goico J, Ochoa C, Tan S, Berkowitz K, Hodis HN, Azen SP: Preservation of pancreatic b-cell function and prevention of type 2 diabetes by pharmacological treatment of insulin resistance in high-risk hispanic women. Diabetes 2002, 51:2796-2803

92. The Diabetes Prevention Program Research Group: Prevention of type 2 diabetes with troglitazone in the Diabetes Prevention Program. Diabetes 2005, 54:1150-1156.

93. Xiang AH, Peters RK, Kjos SL, Marroquin A, Goico J, Ochoa C, Kawakubo M, Buchanan TA: Effect of pioglitazone on pancreatic b-cell function and diabetes risk in Hispanic women with prior gestational diabetes. Diabetes 2006, 55:517-522.

94. The DREAM Trial Investigators: Effect of rosiglitazone on the frequency of diabetes in patients with impaired glucose tolerance or impaired fasting glucose: a randomised controlled trial. Lancet 2006, 368:1096-1105.
95. Nelson MR, Bacanu SA, Mosteller M, Li L, Bowman CE, Roses AD, Lai EH, Ehm MG: Genome-wide approaches to identify pharmacogenetic contributions to adverse drug reactions. Pharmacogenomics J 2009, 9:23-33.

96. Gloyn AL, Pearson ER, Antcliff JF, Proks P, Bruining GJ, Slingerland AS, Howard $\mathrm{N}$, Srinivasan S, Silva JM, Molnes J, Edghill EL, Frayling TM, Temple IK, Mackay D, Shield JP, Sumnik Z, van RA, Wales JK, Clark P, Gorman S, Aisenberg J, Ellard S, Njolstad PR, Ashcroft FM, Hattersley AT: Activating mutations in the gene encoding the ATP-sensitive potassium-channel subunit Kir6.2 and permanent neonatal diabetes. N Engl J Med 2004, 350:1838-1849.

97. Pearson ER, Flechtner I, Njolstad PR, Malecki MT, Flanagan SE, Larkin B, Ashcroft FM, Klimes I, Codner E, lotova V, Slingerland AS, Shield J, Robert JJ, Holst JJ, Clark PM, Ellard S, Sovik O, Polak M, Hattersley AT: Switching from insulin to oral sulfonylureas in patients with diabetes due to Kir6.2 mutations. N Engl J Med 2006, 355:467-477.

98. Holstein A, Hahn M, Stumvoll M, Kovacs P: The E23K variant of KCNJ11 and the risk for severe sulfonylurea-induced hypoglycemia in patients with type 2 diabetes. Horm Metab Res 2009, 41:387-390.

99. Sesti G, Laratta E, Cardellini M, Andreozzzi F, Del Guerra S, Irace C, Gnasso A, Grupillo M, Lauro R, Hribal ML, Perticone F, Marchetti P: The E23K variant of KCNJ11 encoding the pancreatic beta-cell adenosine 5 '-triphosphatesensitive potassium channel Kir6.2 is associaed with an increased risk of secondary failure to sulfonylurea in patients with type 2 diabetes. $J$ Clin Endocrinol Metab 2006, 91:2334-2339.

100. Snitker S, Watanabe RM, Ani I, Xiang AH, Marroquin A, Ochoa C, Goico J, Shuldiner AR, Buchanan TA: Changes in insulin sensitivity in response to troglitazone do not differ between subjects with and without the common, functional Pro12Ala PPAR-g-2 gene variant: results from the Troglitazone in Prevention of Diabetes (TRIPOD) study. Diabetes Care 2004 27:1365-1368.

101. Wolford JK, Yeatts KA, Dhanjal SK, Black MH, Xiang AH, Buchanan TA, Watanabe RM: Sequence variation in PPARG may underlie differential response to troglitazone. Diabetes 2005, 54:3319-3325.

102. Kang ES, Park SY, Kim HJ, Ahn CW, Nam M, Cha BS, Lim SK, Kim KR, Lee HC The influence of adiponectin gene polymorphism on the rosiglitazone response in patients with type 2 diabetes. Diabetes Care 2005, 28:1139-1144.

103. Florez JC, Jablonski KA, Sun MW, Bayley N, Kahn SE, Shamoon H, Hamman RF, Knowler WC, Nathan DM, Altshuler D: Effects of the type 2 diabetesassociated PPARG P12A polymorphism on progression to diabetes and response to troglitazone. J Clin Endocrinol Metab 2007, 92:1502-1509.

104. Distefano JK, Watanabe RM: Pharmacogenetics of anti-diabetes drugs. Pharmaceuticals (Basel) 2010, 3:2610-2646.

105. Franks PW, Jablonski KA, Delahanty LM, McAteer JB, Kahn SE, Knowler WC, Florez JC: Assessing gene-treatment interactions at the FTO and INSIG2 loci on obesity-related traits in the Diabetes Prevention Program. Diabetologia 2008, 51:2214-2223.

106. Li S, Zhao JH, Luan J, Ekelund U, Luben RN, Khaw KT, Wareham NJ, Loos RJ: Physical activity attenuates the genetic predisposition to obesity in 20,000 men and women from EPIC-Norfolk prospective population study. PLOS Med 2010, 7:e1000332.

doi:10.1186/gm232

Cite this article as: Watanabe RM: Inherited destiny? Genetics and gestational diabetes mellitus. Genome Medicine 2011, 3:18. 